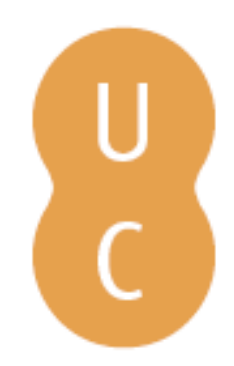

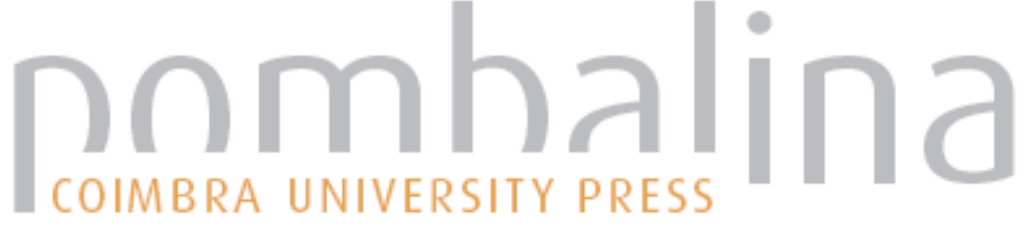

\section{Characterizing the secondary peak of lberian fires in March}

Autor(es): $\quad$ DaCamara, Carlos C.; Trigo, Ricardo M.; Nascimento, Manuel L.

Publicado por: Imprensa da Universidade de Coimbra

URL

persistente:

URI:http://hdl.handle.net/10316.2/34158

DOI:

DOI:http://dx.doi.org/10.14195/978-989-26-0884-6_184

Accessed : $\quad$ 26-Apr-2023 12:21:11

A navegação consulta e descarregamento dos títulos inseridos nas Bibliotecas Digitais UC Digitalis, UC Pombalina e UC Impactum, pressupõem a aceitação plena e sem reservas dos Termos e Condições de Uso destas Bibliotecas Digitais, disponíveis em https://digitalis.uc.pt/pt-pt/termos.

Conforme exposto nos referidos Termos e Condições de Uso, o descarregamento de títulos de acesso restrito requer uma licença válida de autorização devendo o utilizador aceder ao(s) documento(s) a partir de um endereço de IP da instituição detentora da supramencionada licença.

Ao utilizador é apenas permitido o descarregamento para uso pessoal, pelo que o emprego do(s) título(s) descarregado(s) para outro fim, designadamente comercial, carece de autorização do respetivo autor ou editor da obra.

Na medida em que todas as obras da UC Digitalis se encontram protegidas pelo Código do Direito de Autor e Direitos Conexos e demais legislação aplicável, toda a cópia, parcial ou total, deste documento, nos casos em que é legalmente admitida, deverá conter ou fazer-se acompanhar por este aviso. 


\section{ADVANCES IN}

Forest Fire

\section{RESEARCH}

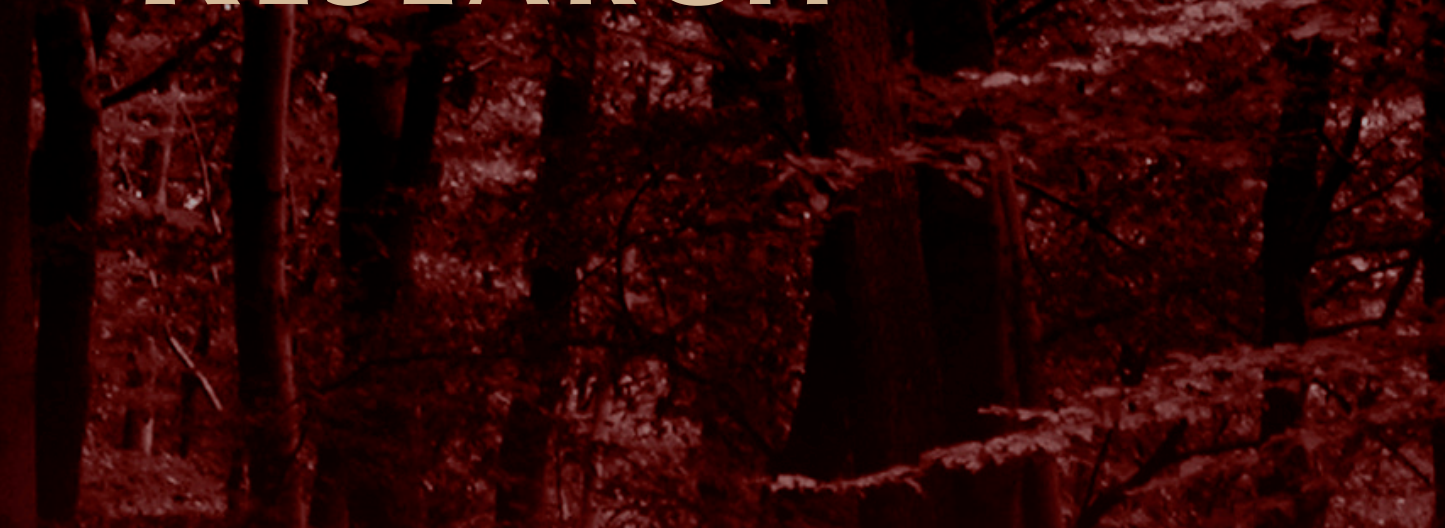

\section{DOMINGOS XAVIER VIEGAS}

\section{EDITOR}




\title{
Characterizing the secondary peak of Iberian fires in March
}

\author{
Carlos C. DaCamara, Ricardo M. Trigo, Manuel L. Nascimento \\ Instituto Dom Luiz, Faculdade de Ciências, Universidade de Lisboa, 1749-016 Lisboa, Portugal, \\ cdcamara@fc.ul.pt, rmtrigo@fc.ul.pt, mlnascimento@fc.ul.pt
}

\begin{abstract}
Mediterranean Europe is strongly affected by wildfires that burn half a million of hectares of vegetation cover every year causing extensive economic losses and ecological damage. Most studies about fire activity over the Iberian Peninsula (IP) are focused on the summer months, from June to September, as these correspond to the vast majority of BA, but it is important to note the occurrence of a secondary peak during late winter and early spring. This peak is particularly prominent during the month of March, although its relevance changes considerably for different Iberian regions. While the causes of fire activity in March in IP are mainly anthropogenic, either because of negligence or arson, meteorological factors also play an important role in the ignition and spread of wildfires.

The main aims of the present study are threefold: 1) to identify the areas of the IP where fires in March play an important role and have a coherent inter-annual variability; 2) to relate burned areas in March to meteorological danger and 3) to characterize the synoptic conditions that constitute the meteorological background in extreme events (i.e. large burned areas in March).
\end{abstract}

Keywords: burned area, meteorological factors, extreme events

\section{Introduction}

Mediterranean Europe is strongly affected by wildfires that burn half a million of hectares of vegetation cover every year causing extensive economic losses and ecological damage (San-Miguel-Ayanz et al. 2012). According to reports of the European Commission (European Commission, 2011), during the period 1980-2010 the Iberian Peninsula (IP) has contributed to $60 \%$ of the total burned area of 14,620,968 ha that was recorded in five Southern Member States (Portugal, Spain, France, Italy and Greece). As discussed in previous works, e.g. in Trigo et al. (2013), this may be attributed to a number of factors that include both natural and anthropogenic factors. Natural factors include geographical location, topography, vegetation cover as well as climate background and extreme meteorological conditions (Pausas, 2004; Pereira et al., 2005; Trigo et al., 2006). Anthropogenic factors range from land management practices and fire prevention, management and suppression efforts, up to socioeconomic and demographic trends (Cueva et al., 2006; Costa et al., 2010).

Most studies about fire activity over IP are focused in the summer months, from June to September, as these correspond to the vast majority of BA. However, it is important to note the occurrence of a secondary peak during late winter and early spring. This peak is especially conspicuous in the month of March, although its relevance changes considerably for different Iberian regions (Trigo et al. 2013). The existence of a secondary peak was known for some northern sectors of IP, but the absence of a pan-Iberian dataset undermined a more thorough analysis on the exact nature and extension of this secondary peak. This caveat was solved to a large extent in Trigo et al. (2013) that have used a consistent dataset for the entire Iberian region and applied a k-means cluster analysis to identify large areas characterized by similar fire regimes. The most compelling results were obtained for four clusters (Northwestern, Northern, Southwestern and Eastern) whose spatial patterns and seasonal fire regimes are shown to be related with constraining factors such as topography, vegetation cover and climate conditions. Interestingly, two of the identified clusters present two maxima, with the Northwestern cluster revealing a much larger peak in August and a smaller one in March. The northern most areas of Iberia are concentrated in the Northern cluster that presents two peaks, both comparable in 
magnitude (although relatively small), in early spring (March) and late summer (September). Finally, the two remaining clusters (Southwestern and Eastern) are characterized by a single summer maximum in either July or August. Therefore, considering the fact that these March fires affect not only ecosystems but also local populations, they should not be neglected, and deserve to be further investigated. While the causes of fire activity in March in IP are mainly anthropogenic, either because of negligence or arson, meteorological factors also play an important role in the ignition and spread of wildfires. The main aims of the present study are threefold: 1) to identify the areas of the IP where fires in March play an important role and have a coherent inter-annual variability; 2) to relate burned areas in March to meteorological danger and 3) to characterize the synoptic conditions that constitute the meteorological background in extreme events (i.e. large burned areas in March).

For that purpose, monthly amounts of BA are analyzed for each administrative region of Portugal and Spain, covering the period 1980-2005. The study area is first identified based on a ranking of relative $\mathrm{BA}$ in each region (i.e. in terms of percentage of the total area of the region) and two regions with distinct inter-annual variability are defined based on cluster analysis performed on time series of BA. The impact of meteorological danger is then assessed by means of the so-called Daily Severity Rating (DSR), an indicator of fire danger which is part of the Canadian Forest Fire Weather Index System (CFFWIS). Finally, meteorological charts of sea-level pressure, $500 \mathrm{hPa}$ height, $2 \mathrm{~m}$-temperature and zonal and meridional components of the wind are analyzed for extreme years of BA during the period of study.

\section{Data and methods}

\subsection{Burnt area data}

Fire data were supplied by the Autoridade Florestal Nacional (AFN, 2011) and by the Dirección General de Biodiversidad, the national authorities for Portugal and Spain, respectively. The datasets cover the period from 1980 to 2005. Following Trigo et al. (2013), data for both countries were merged into a single dataset of monthly amounts of BA, spatially organized into administrative regions, respectively distritos for Portugal and provincias for Spain. Therefore, the database spatial domain is constituted by a total of 66 regions, 18 for Portugal and 48 for Spain.

\subsection{Meteorological data}

Following Pereira et al. (2013) meteorological danger of fire was evaluated based on DSR which integrates the Canadian Forest Fire Danger Rating System (CFFDRS). This system is composed of a set of quantitative indices of fire potential, which are used as guides in a wide variety of fire management activities. For instance, DSR is considered to be a good indicator about the expected efforts required for fire suppression and was specifically designed for averaging either in time or in space (Van Wagner 1987).

Daily values of all components of CFFWIS, in particular DSR, were computed based on ERA-interim reanalysis data at 12 UTC for the period 1979-2012. DSR fields are defined in a $0.05^{\circ}$ by $0.05^{\circ}$ grid covering the region delimited by latitude circles $35^{\circ}$ and $45^{\circ} \mathrm{N}$, and by meridians $10^{\circ} \mathrm{W}$ and $5^{\circ} \mathrm{E}$ which encompasses IP as well as a part of France and North Africa.

\subsection{Synoptic conditions}

Information about synoptic conditions associated with extreme events was obtained using the Koninklijk Nederlands Meteorologisch Instituut (KNMI) Climate Explorer tool. Synoptic information consists of maps of monthly anomalies defined as departures from climatological normal of 1981-2010 of sea-level pressure (SLP), $500 \mathrm{hPa}$ geopotential fields (Z500), 2m-temperature (T2). Besides the aforementioned anomalies, monthly means of zonal and meridional wind magnitudes at 10 meters (U10 and V10, respectively) were also used. Maps of SLP and Z500 are defined on a large window, centred over IP and covering Europe and North Africa, delimited by latitude circles of $30^{\circ}$ and $70^{\circ} \mathrm{N}$ 
and by meridians of $45^{\circ} \mathrm{W}$ and $45^{\circ} \mathrm{E}$, whereas maps of T2, U10 and V10 are defined on a smaller window covering the North of IP, defined between $40^{\circ}$ and $45^{\circ} \mathrm{N}$ and between $10^{\circ} \mathrm{W}$ and the Greenwich meridian.

\section{Results}

\subsection{Spatial analysis of BA in March}

The total amount of BA in March, for each region, was sorted in descending order. However, because the considered regions have quite different surface areas, the analysis was performed on relative values of BA for each region, which were obtained by dividing the total amount of BA of each region by the total area of the region. All but one region that rank in the first 24 are spatially contiguous, spreading over the North and Northwest of IP. The exception is the region of Castellon (located over the East of IP) that ranks 19. This suggests considering the 23 contiguous regions as the study area for March BA over IP.

\subsection{Inter-annual variability of $\mathrm{BA}$ in March}

In order to identify regions of consistent inter-annual variability within the study area, a k-means clustering analysis was performed on time series of March BA for each region.

The k-means clustering analysis was applied to the 23 regions that constitute the study area, each one viewed as a point in a 26 dimensional space, each axis being the value of BA (normalized in time) for a specific year during the 26-year period 1980-2005. The k-means clustering analysis is performed by pre-specifying a given number $k$ clusters ( $k$ was set to 2 ) and by successively assigning each point to the nearest centroid of the clustering, computing the centroids of obtained new clusters, and repeating the process until the assignment of members does not change. As shown in Fig 1, the two clusters obtained, hereafter referred to as East cluster and West cluster, present spatial continuity and are separated from each other by the Cantabrian mountain ranges.

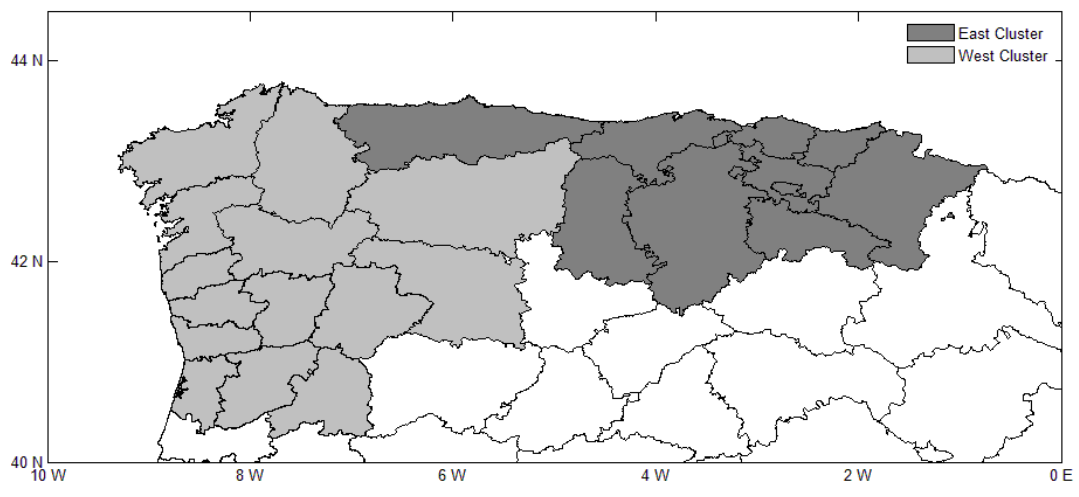

Figure 1. The k-means determined clusters of Northern Iberia

As shown in Figure 2, the time series for the two clusters of normalized burnt area present distinct behaviour, especially in terms of years of extreme BA. The years of 1981 and 1989 correspond to high values of burnt area for the East cluster, whereas the years of 1997 and 2000 are the ones of higher values of burnt area for the West cluster. The year of 1997 is especially conspicuous since both regions present high values of burnt area. 


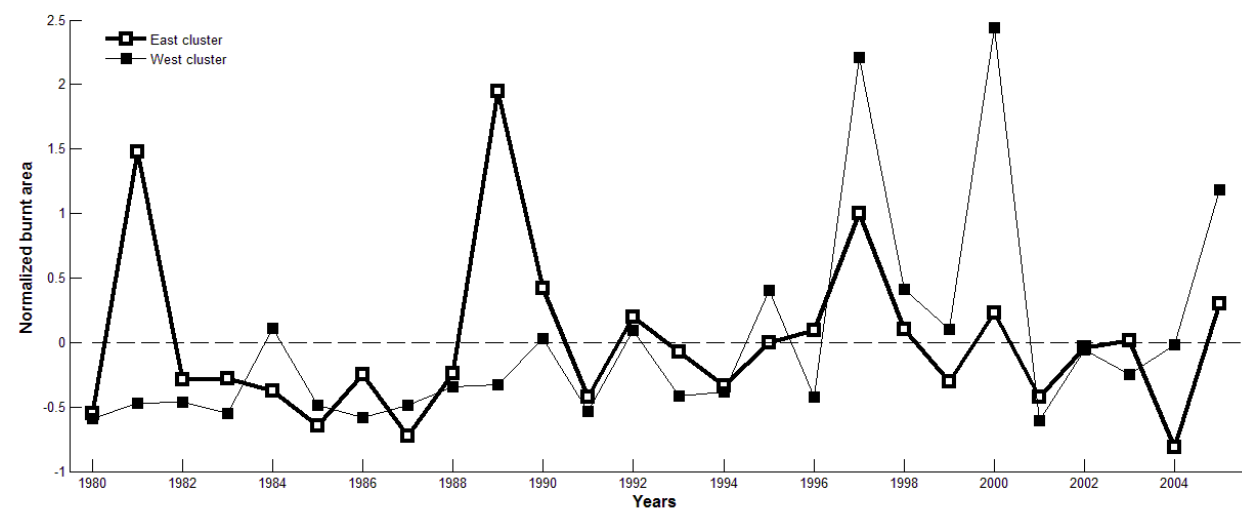

Figure 2. Time series of normalized BA for East and West clusters

Using polygon shapefiles for the administrative regions, a spatial mask for each cluster was defined and spatial means of daily values of DSR in March were accordingly computed. Then, for each year and for each cluster, the average of these DSR daily values above the monthly median was assigned to each year. This value, hereafter referred to as DSR+, is expected to reflect (at the monthly level) the presence of the usually small number of days that have high values of DSR and are associated to large fire activity that virtually explain the monthly amounts of BA. This is illustrated in Figure 3, where high values of DSR, for the West cluster in 2005, concentrate in a period of 5 days, from March $16^{\text {th }}$ to $20^{\text {th }}$.

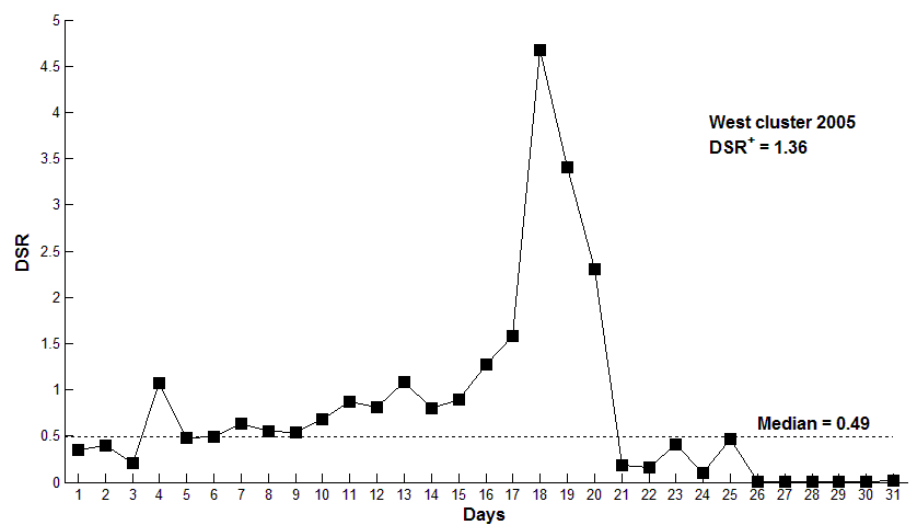

Figure 3. Time series of daily values of DSR for March 2005, for the West cluster

The time series of $\mathrm{DSR}^{+}$for both clusters are shown in Figure 4. As expected, because of the magnitude of the spatial scale associated to synoptic conditions, the two time series present a coherent temporal behaviour which reflects on the value of the correlation between the two $(r=0.88)$. The peak in both series occurring in 1997 is worth being noted since it corresponds to a year of high values of NBA in both East and West clusters. The same happens in 2005 which is associated to high values of NBA in both clusters and to high values of $\mathrm{DSR}^{+}$in both time series. The year of 2000, associated to a high value of NBA in the West cluster is also associated to a high value of DSR ${ }^{+}$. However, the years of 1981 and 1989, where peaks of NBA may be identified in the East cluster, are associated to relatively low values of $\mathrm{DSR}^{+}$. 


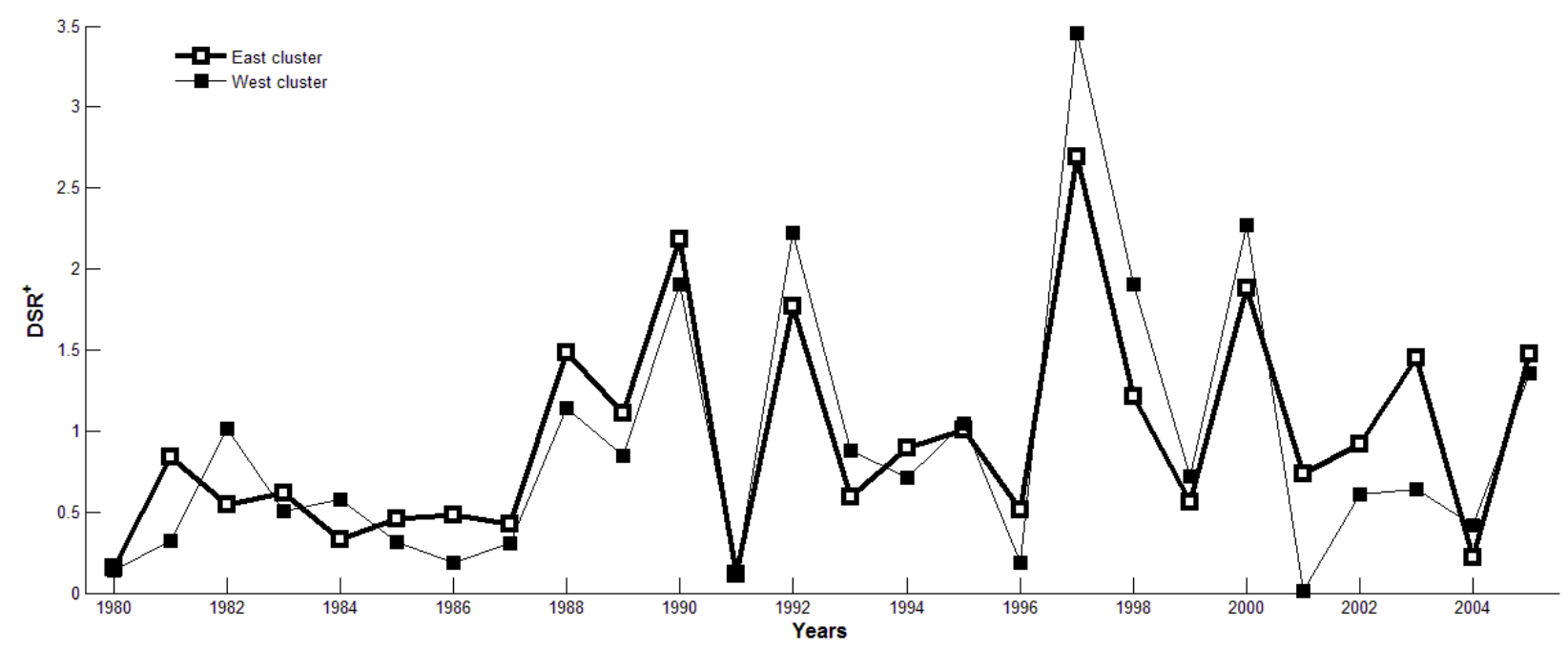

Figure 4. As in Figure 2 but for time series of DSR+.

\subsection{The role of meteorological danger}

Results from the previous sections suggest that the relationship between DSR+ and NBA in each cluster should be further investigated. Figure 5 presents scatter plots of DSR+ versus NBA for the West cluster (left panel) and the East cluster (right panel). In the case of the West cluster, results provide evidence of a linear relationship between the two analyzed time series. A linear model was fitted by least square regression which explains almost two thirds $(65 \%)$ of the total variance.

In the case of the East cluster the above-mentioned year of 1981 and 1989 appear as outliers from a distribution that again suggests a linear relationship between DSR+ and NBA. These two outliers were disregarded and a linear regression model was fitted to the data, with good results, explaining three quarters $(75 \%)$ of the total variance.
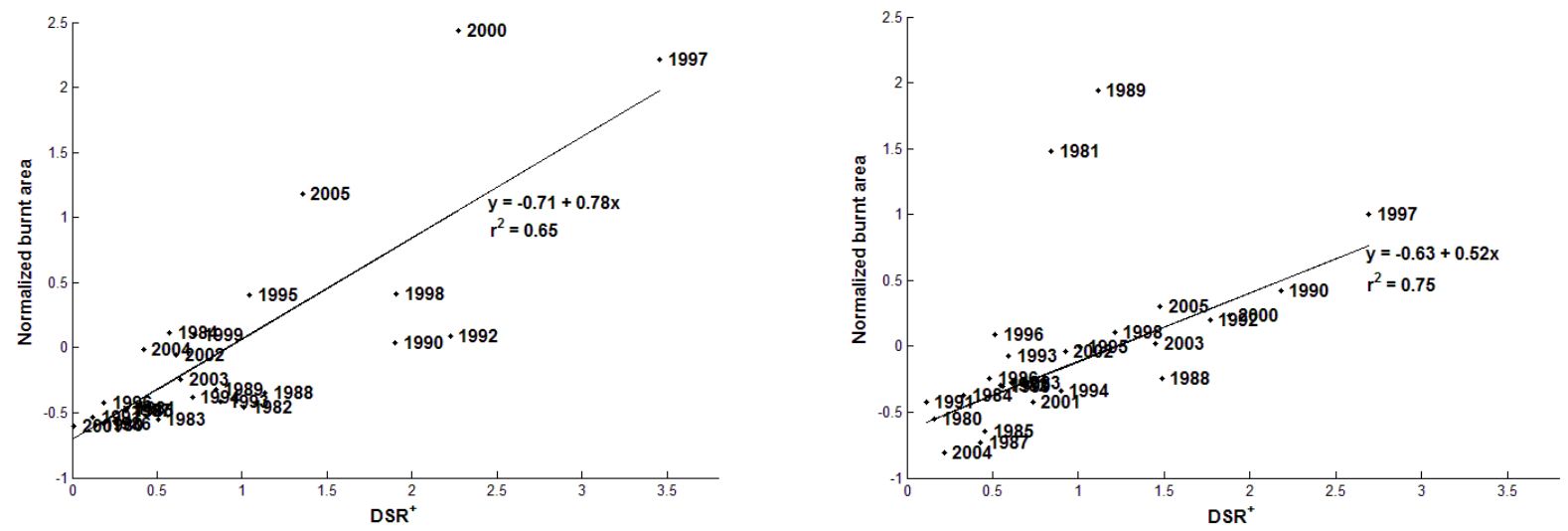

Figure 5. Scatter plots of NBA vs. DSR for the West (left panel) and East (right panel) clusters. Straight lines were obtained by linear regression that was applied to all years in the case of the West cluster and to all years but 1981 and 1989 in the case of the East cluster.

Results suggest that inter-annual variability of March NBA in the two clusters is linked to meteorological conditions that induce meteorological danger of fire ignition and fire spread. Nevertheless, the two highest years of BA in the East cluster present a different behaviour that deserves 
to be further investigated. However, and as to be expected, even for all remaining cases in both clusters there is still a substantial amount of inter-annual variability that is not explained by such a simple model (about one third and one fourth of total variability for West and East clusters, respectively).

\subsection{Atmospheric patterns associated to extreme years of burnt area}

The linkage between $\mathrm{DSR}^{+}$and NBA was further investigated by analyzing the synoptic circulation patterns that prevailed for years characterized by very large amounts of March NBA for each or both clusters. Figure 6 presents the values of NBA in descending order for the West cluster (left panel) and the East cluster (right panel). The four (six) highest years for the West (East) cluster are labelled. First a detailed analysis will be presented for the year of 2000, associated to the highest value of NBA in the West cluster. Then a similar analysis is provided for the year 1989, associated to the highest value of NBA in the East cluster and finally for the year 1997 associated to high values of NBA in both clusters (ranking $2^{\text {nd }}$ and $3^{\text {rd }}$ in the West and East clusters, respectively).

As shown in Figure 7 (top panel), the extreme event of 2000 covers the majority of the area of the West cluster, with all regions ranging from the top to the $5^{\text {th }}$ position, half of the 14 regions occupying the $1^{\text {st }}$ rank in BA.

In the case of the extreme event of 1989 (Figure 7, central panel), the large majority of regions that form the East cluster occupy the first three positions, the exception being the provinces of Asturias and Cantabria, located in the northwest coast of the East cluster.

In the case of 1997 (Figure 7, bottom panel), 19 regions out of the 23 regions that form the East and West clusters occupy the first five positions, 12 of them ranking $1^{\text {st }}$ and $2^{\text {nd }}$. The exceptions are the easternmost regions of Guipúzcoa, Vizcaya, Navarra and La Rioja that rank in positions 12, 13, 15 and 19.
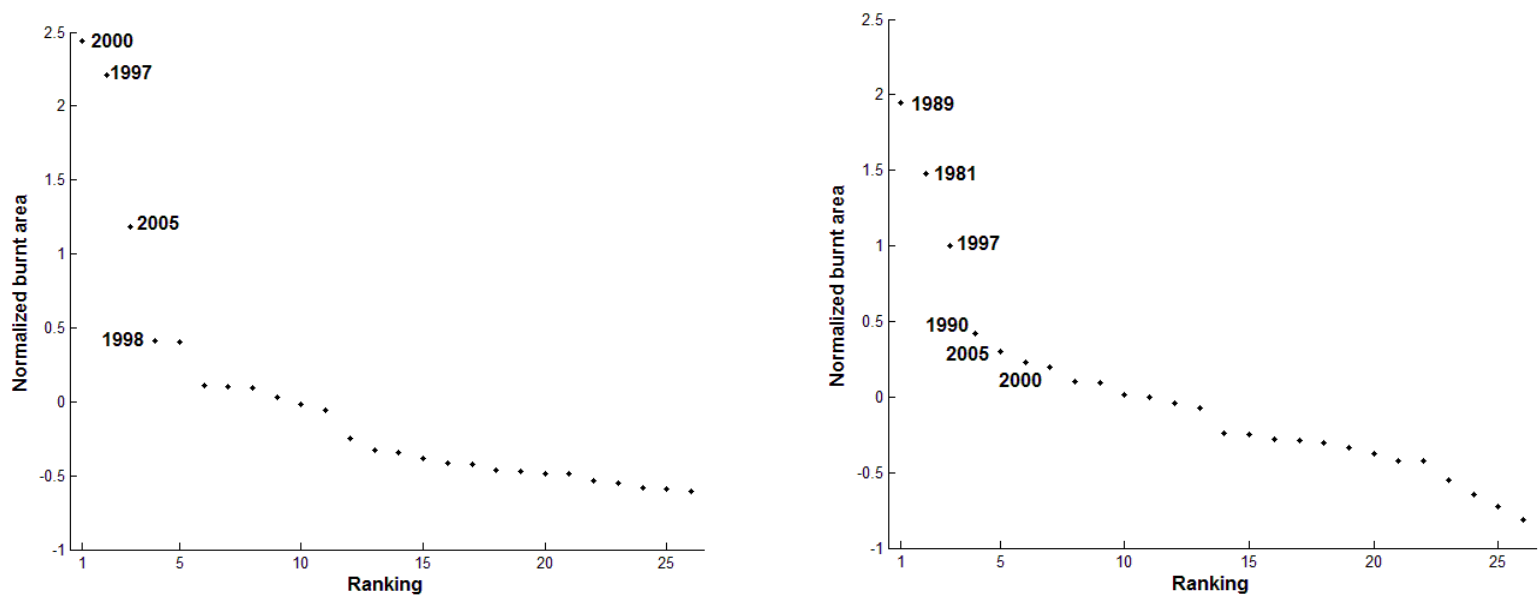

Figure 6. Values of NBA sorted in descending order for the West (left panel) and East (right panel) clusters. 


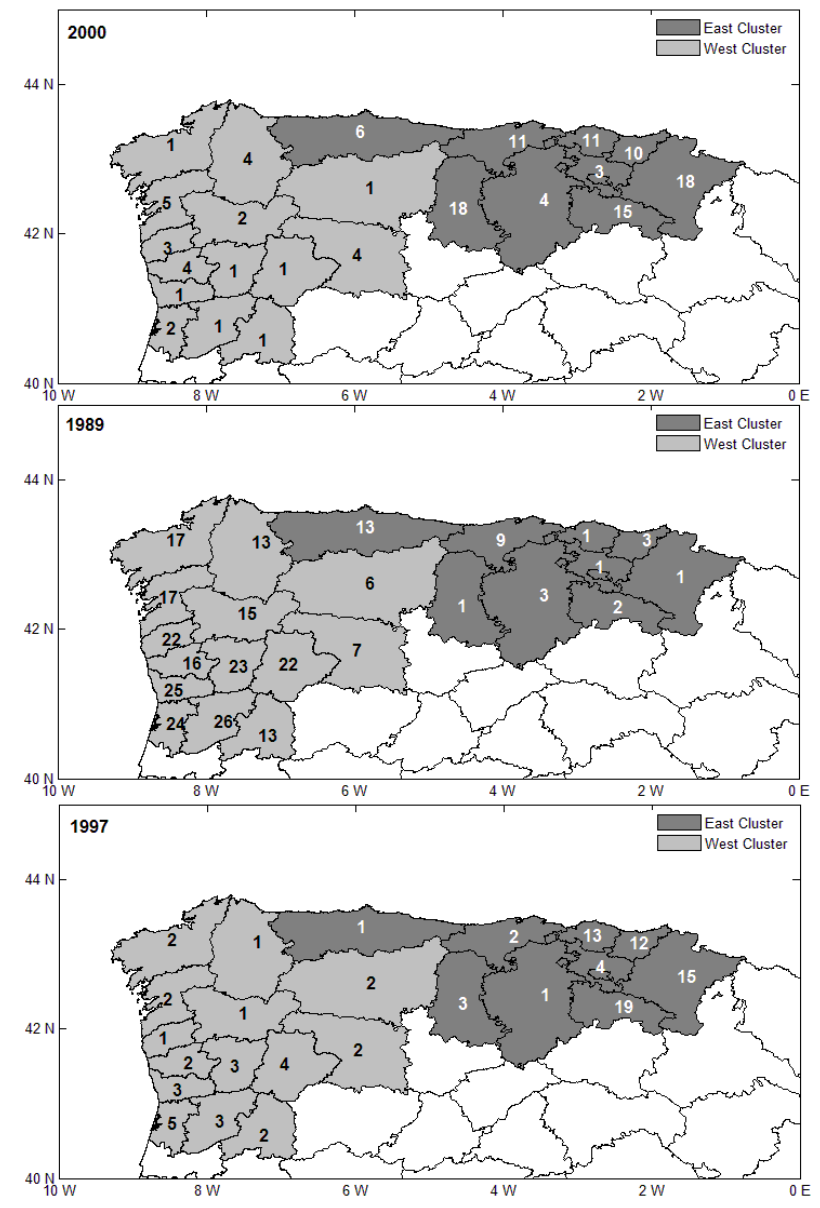

Figure 7. Ranking of administrative regions in the study area according to the amount of BA for the extreme events of March 2000 (top panel), March 1989 (middle panel) and March 1997 (bottom panel).

\subsection{The extreme cases in the West cluster (March 2000), the East cluster (March 1989) and both clusters (March 1997)}

The atmospheric circulation relative to March 2000 is characterized by the presence of an intense anticyclonic pattern centred just west of the British Islands (Fig 8, top panel). This structure is characterized by positive anomalies of SLP (Figure 8, top left panel) and geopotential height at the $500 \mathrm{hPa}$ level, which are characteristic of a hot quasi-barotropic anomaly. The location of such patterns, farther North than usual, corresponds to a typical Winter-Spring blocking pattern (Trigo et al., 2004) that disrupts the usual path of low pressure systems from the Atlantic towards Europe. The negative values of zonal and meridional winds for the West cluster point to a North-eastern continental air flow which results in negative temperature anomalies along the northern coast of Spain as a consequence of the advection of cold air from northern Europe (Trigo et al., 2004). Positive temperature anomalies may however be observed for Northern Portugal and Galicia (Figure 8, top right panel), as a result from an intense Föhn effect over the Cantabrian mountains with warmer and drier air descending the southern flank. The warm temperatures and downwind are associated to meteorological conditions favouring the onset and spreading of fires, which translates into an increase of meteorological danger of fire. This is clearly shown in the daily time series of DSR for March 2000 where a steady increase may be observed since the $7^{\text {th }}$ until the $20^{\text {th }}$ of March (Figure 9, top left panel).

When compared with March 2000, the atmospheric circulation of March 1989 presents an almost inverted pattern, with an intense low pressure system crossing the Atlantic with its centre placed just south of Iceland (Figure 8, central panel). The presence at high latitudes of highly negative anomalies of SLP (Figure 8, central left panel) and geopotential height at the $500 \mathrm{hPa}$ level associated with 
positive anomalies in the lower latitudes induce stronger than usual westerly winds, with the advection of warm and moist being responsible for the positive anomalies that are observed over the study area. Warming of air is further enhanced by the Föhn effect when the flow crosses the Cantabrian mountain ranges, resulting in hot (and dry) anomalies close to the Basque country and Pyrenees that could induce fire activity (Figure 8, central right panel). This is supported by the behaviour of time series of DSR that presents a sequence of three small peaks of increasing amplitude in the first 17 days of March, the third one centred on March $16^{\text {th }}$, followed by a very large peek centred on March $27^{\text {th }}$ (Figure 9, top right panel). The fact that extreme values of DSR are concentrated on this last very short period of time makes it very difficult to perform an analysis of the events at the monthly scale and explains the apparently anomalous behaviour of March 1989 when looking at scatter plots of DSR ${ }^{+}$versus NBA (Figure 5, right panel).
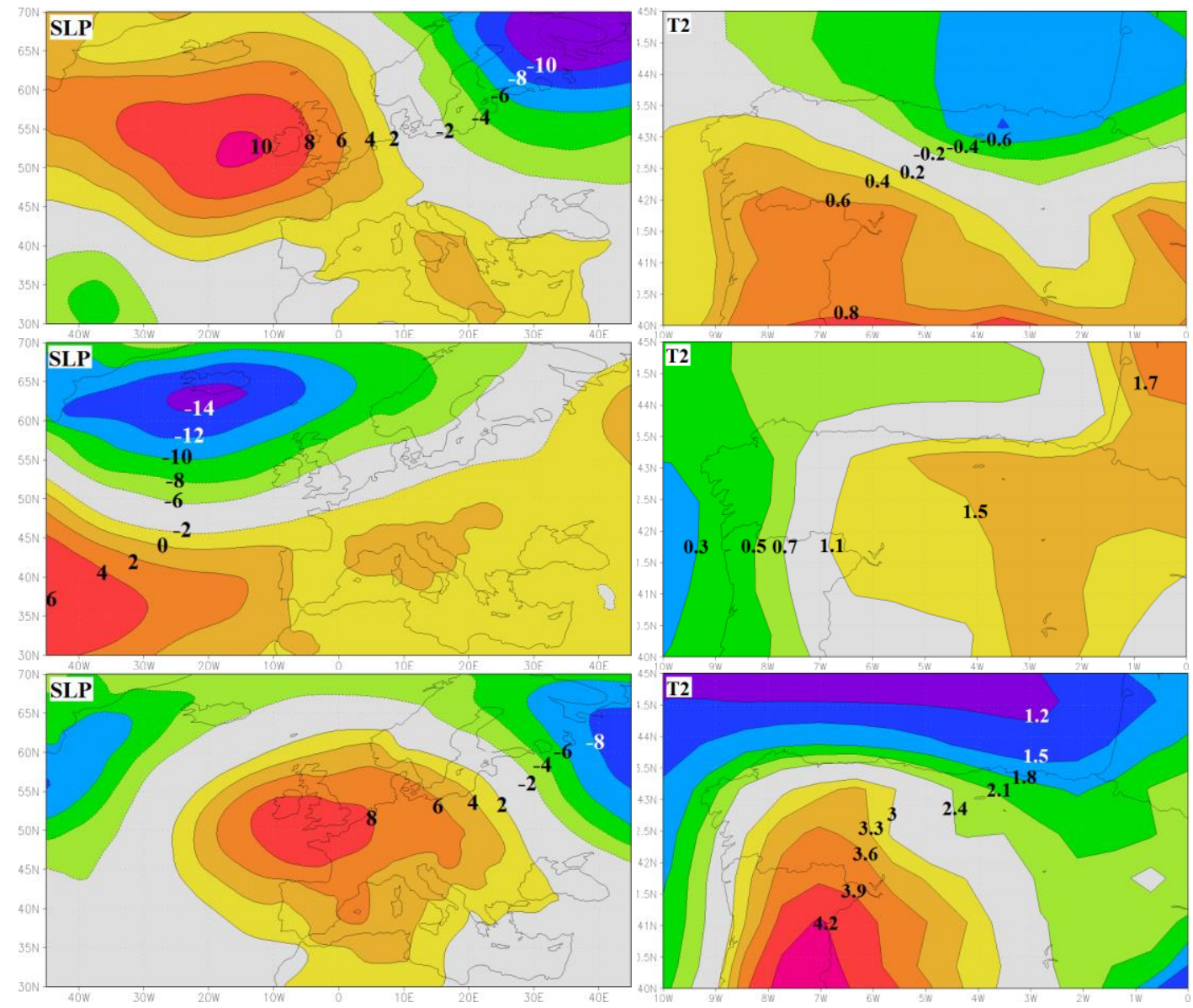

Fig 8-Monthly anomaly charts for the West cluster of March 2000 (top panel), the East cluster of March 1989 (central panel) and for both clusters of March 1997 for two atmospheric fields. Contour lines delineate anomaly fields of SLP (hPa), and T2 $\left({ }^{\circ} \mathrm{C}\right)$

The atmospheric circulation of March 1997 is very similar to the one of March 2000, being dominated by a strong anticyclonic pattern centred above the English Channel (Figure 8, bottom panel). Two intense positive anomalies of both SLP (Figure 8, bottom left panel) and Z500 may be again identified, suggesting a hot barotropic anomaly, typical of a blocking pattern. The resulting Northeastern winds induce a small positive anomaly over the easternmost regions of the East cluster and the air is further warmed by the Föhn effect when crossing the Cantabrian Mountains into Galicia and Northern Portugal. This effect is clearly illustrated by the daily time series of DSR over the West and East clusters (Figure 9, bottom panel), where two large peaks may be identified in the last ten days of March, the peaks in the time series of the West cluster being substantially higher than the 
corresponding ones in the East cluster. The two time series present a coherent variability during the month, especially during the last 10 days, a feature that explains the high values of burned area that were registered in both clusters.
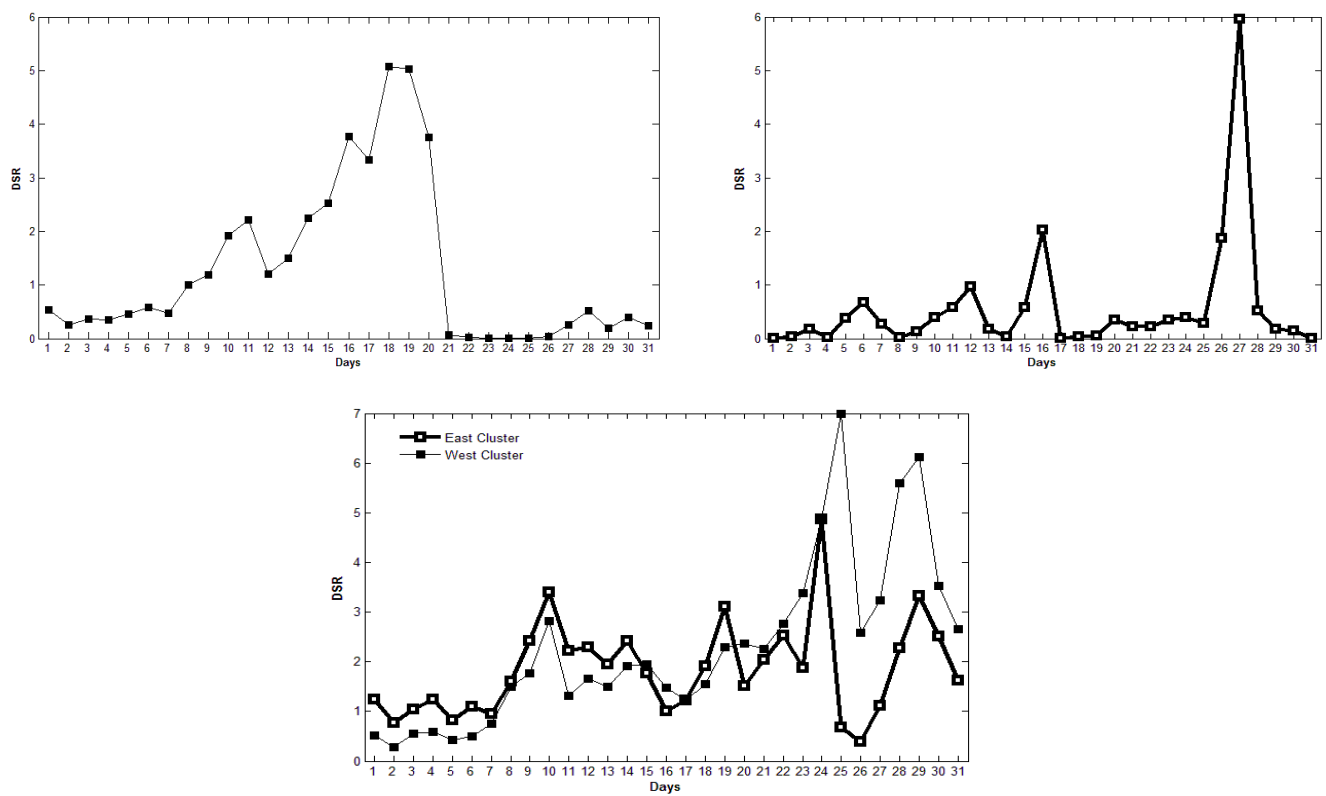

Fig 9 - Daily values of mean DSR for the West cluster of March 2000 (top left panel), for the East cluster of March 1989 (top right panel) and both clusters of March 1997 (bottom panel)

\subsection{The role of large-scale atmospheric patterns}

The role played by large scale atmospheric patterns in the establishment of meteorological conditions favouring the occurrence of fire events may be put into evidence by analyzing the atmospheric patterns of 1989, 1997 and 2000, associated to these three extreme events. As shown in Figure 8, in all three events the study area is crossed either by Northeastern flow (cases of March 2000 and of March 1997) or by Southwestern flow (case of March 1989); in all cases the flow crosses the Cantabrian mountains and the associated Föhn effect induces warm and dry conditions downstream where fire activity is observed.

Such large scale flow is induced by well-defined anomalies west of the British Isles, with a barotropic structure which are either positive anomalies (of blocking-type) or negative. These barotropic anomalies tend to be stationary for several days and together with the Föhn effect are on the origin of the observed peaks of daily DSR (Figure 9), i.e. of meteorological danger.

This simple conceptual model was applied to the seven cases where amounts of BA ranked in the top four positions in the case of the West cluster and in the top six positions in the case of the East cluster (i.e. the two outliers of 1981 and 1989 and the following four years of higher BA). The chosen years are identified in Figure 6 and in Table 1, the latter showing the ranks and the type of anomaly located in the Atlantic Ocean near the British Isles.

It may be observed that the two extreme cases in the East cluster (March 1981 and 1989) are associated to an intense negative anomaly that steers Southwestern flow and that all remaining 5 cases are associated to a blocking-type positive anomalies that induces Northeastern flow. It may be further noted that 3 out of these 5 cases (i.e. March 1997, March 2000 and March 2005) correspond to high values of BA in both clusters. 
Table 1. Extreme years, West and East ranking and occurrence of blocking event.

\begin{tabular}{|cccc} 
Year & $\begin{array}{c}\text { Large-scale } \\
\text { pattern }\end{array}$ & $\begin{array}{c}\text { West cluster } \\
\text { rank }\end{array}$ & $\begin{array}{c}\text { East } \\
\text { cluster } \\
\text { rank }\end{array}$ \\
\hline 1981 & Negative anomaly & 19 & $\mathbf{2}$ \\
1989 & Negative anomaly & 13 & $\mathbf{1}$ \\
1990 & Positive anomaly & 9 & $\mathbf{4}$ \\
1997 & Positive anomaly & $\mathbf{2}$ & $\mathbf{3}$ \\
1998 & Positive anomaly & $\mathbf{4}$ & 8 \\
2000 & Positive anomaly & $\mathbf{1}$ & $\mathbf{6}$ \\
2005 & Positive anomaly & $\mathbf{3}$ & $\mathbf{5}$
\end{tabular}

\section{Conclusions}

A study was performed on BA in the IP associated to fire activity in March. The study relies on monthly values of BA for a set of 66 regions covering the period 1980-2005 (Trigo et al., 2013). The annual cycle of BA for the entire IP was determined, showing two peaks of BA, a first large peak centred in August and spreading over summer and a secondary one centred in March and spreading over late winter-early spring.

The 66 regions were sorted by decreasing order of relative BA, which was obtained by dividing the total amount of BA for each region by the corresponding total area, therefore ensuring equal weights from the regions. The ranking procedure allowed defining a spatially contiguous study area formed by 23 regions that ranked in the first 24 places; the region of Castellon, that ranked $19^{\text {th }}$ was discarded because of the spatial location, out of the area covered by the remaining ones.

Time series of BA for each of the 23 regions were normalized by subtracting the respective time mean and dividing by the standard deviation and a cluster analysis was performed on time series of NBA leading to the identification of two clusters, each one presenting a characteristic inter-annual variability. The two clusters, the so-called West cluster and East cluster, are formed by contiguous regions and are separated by the Cantabrian Mountains. Extreme events were identified in each or both clusters, namely March 1997 for both clusters, March 2000 and March 2005 for the West cluster, and March 1981 and March 1989 for the East cluster.

For each cluster, the associated meteorological conditions were analyzed by inspecting time series of DSR, an index of meteorological danger, i.e. of meteorological conditions that might induce fire onset and fire spread. Because fire events tend to be associated to a small number of days with higher meteorological danger, the monthly values of meteorological danger were assigned in terms of $\mathrm{DSR}^{+}$, i.e. on time means performed on days with DSR above the monthly median. Time series of $\mathrm{DSR}^{+}$for each cluster show peaks in March 1997 for both clusters, as well as in 2000 and 2005 for the West cluster. These results indicate that high levels of meteorological fire danger are associated to large values of NBA; however, the years of 1981 and 1989, associated to the highest values of NBA in the East cluster, present rather low values of $\mathrm{DSR}^{+}$in that cluster.

In order to further investigate the relationship between fire danger and monthly burned area, linear regression models were developed relating $\mathrm{DSR}^{+}$and NBA in each cluster. The models were able to provide good results in both the West and the East clusters, but in the case of the latter cluster the extreme years of 1981 and 1989 had to be disregarded. Results suggest that inter-annual variability of March NBA in the two clusters may be partly understood in terms of the prevalence of meteorological conditions that induce meteorological danger of fire ignition and fire spread.

The role of meteorological conditions was further investigated by analysing the synoptic atmospheric circulation that prevailed during March of the extreme events in the West cluster (March 2000), in the East cluster (March 1989) and in both clusters (March 1997). Results indicate that in all cases, there is an intense prevailing atmospheric flow over the Cantabrian Mountains, either from the Northeast 
(March 2000 and March 1997) or from the Southwest (March 1989), which are driven by the presence of barotropic anomalies located near the British Isles. These steady anomalies are negative in the case of northwestern flow over the study region and positive in case of northeastern flow, being in this associated to blocking-type patterns. The prevailing NE-SW or SW-NE directions are essential since they allow the establishment of a Föhn effect when the air flow crosses the Cantabrian Mountains originating warm and dry air downstream that favours the onset and spreading of fire events.

This simple conceptual model was finally successfully applied to seven cases where amounts of BA ranked in the top four positions in the case of the West cluster and in the top six positions in the case of the East cluster. Results obtained provide a conceptual framework that may assist in developing warning systems of fire danger in March over IP.

\section{References}

Costa L, Thonicke K, Poulter B, Badek F (2010) Sensitivity of Portuguese forest fires to climatic, human, and landscape variables: subnational differences between fire drivers in extreme fire years and decadal averages. Regional Environmental Change 11, 543-551, DOI: 10.1007/s10113-0100169-6

Cueva AV, Barrio JMG, Quero MO, Palomares OS (2006) Recent fire regime in peninsular Spain in relation to forest potential productivity and population density. International Journal of Wildland Fire 15, 397-405, DOI: 10.1071/WF05071

European Commission (2011) Forest Fires in Europe 2010, EUR 24910 EN, Publication Office of the European Union (Luxembourg)

Pausas JG (2004) Changes in fire and climate in the Eastern Iberian Peninsula (Mediterranean Basin). Climatic Change 63, 337-350. DOI: 10.1023/B:CLIM.0000018508.94901.9c

Pereira MG, Trigo RM, DaCamara CC, Pereira JMC, Solange ML (2005) Synoptic patterns associated with large summer forest fires in Portugal. Agricultural and Forest Meteorology 129, 11-25, DOI: 10.1016/j.agrformet.2004.12.007

Pereira MG, Malamud BD, Trigo RM, and Alves PI (2011) The history and characteristics of the 1980-2005 Portuguese rural fire database, Natural Hazards and Earth System Sciences 11, 3343 3358, DOI: 10.5194/nhess-11-3343-2011

Pereira MG, Calado TJ, DaCamara CC, Calheiros T (2013) Potential effects of regional climate change on rural fires in Portugal. Climate Change (in press)

San-Miguel-Ayanz J, Schulte E, Schmuck G, Camia A, Strobl P, Liberta G, Giovando C, Boca R, Sedano F, Kempeneers P, McInerney D, Withmore C, Santos de Oliveira, S, Rodrigues M, Durrant T, Corti P, Oehler F, Vilar L, Amatulli G (2012) Comprehensive Monitoring of Wildfires in Europe: The European Forest Fire Information System (EFFIS). In 'Approaches to Managing Disaster Assessing Hazards, Emergencies and Disaster Impacts' (Ed Tiefenbacher J), 87-108 (InTech: Rijeka, Croatia), DOI: 10.5772/28441

Trigo RM, Trigo IF, DaCamara CC, Osborn TJ (2004) Climate impact of the European winter blocking episodes from the NCEP/NCAR Reanalyses. Climate Dynamics 23, 17-28, DOI: 10.1007/s00382004-0410-4

Trigo RM, Pereira JMC, Pereira MG, Mota B, Calado MT, DaCamara CC, Santo FE (2006) Atmospheric conditions associated with the exceptional fire season of summer 2003 in Portugal. International Journal of Climatology 26, 1741-1757, DOI: 10.1002/joc.1333

Trigo RM, Sousa P, Pereira M, Rasilla D, Gouveia CM (2013) Modeling wildfire activity in Iberia with different atmospheric circulation weather types, International Journal of Climatology, DOI: 10.1002/joc.3749 (in press)

Van Wagner CE (1987) Development and structure of the Canadian Forest Fire Weather Index System. Technical Report No. 35, Canadian Forestry Service (Ottawa). 
Anderberg M.R (1973) Cluster Analysis for Applications, Academic Press, New York San Francisco London, pp. 162-163.

AFN (Autoridade Florestal Nacional). 2011. Statistics: Wildfire Data [Online] Available at: http://www.afn.min-agricultura.pt/portal/dudf/estatisticas/estatistica-2013-dados-sobre-incendiosflorestais [Accessed 1 March 2011].

KNMI Climate Explorer (http://climexp.knmi.nl)

Spanish shapefiles: http://geocommons.com/overlays/168393 [Accessed May 28th 2013]

Portuguese shapefiles: http://geocommons.com/overlays/226435 [Accessed May 28th 2013]

Climate. Forest Ecology and Management 259, 685-697. doi: 10.1016/j.foreco.2009.09.002 